\title{
A study of the structure and morphology of the graphite electrochemical exfoliation products
}

\author{
Yulian A. Khan ${ }^{\mathrm{a}} \bowtie$, Tatyana P. Dyachkova ${ }^{\mathrm{a}}$, Evgeny S. Bakunina ${ }^{\mathrm{a}}$, \\ Elena Yu. Obraztsova ${ }^{a}$, Artyom V. Rukhova, Simone Morais ${ }^{b}$ \\ a Tambov State Technical University, 106, Sovetskaya St., Tambov 392000, Russian Federation, \\ ${ }^{\mathrm{b}}$ Higher Engineering Institute of Porto, Polytechnic Institute of Porto, Porto, 4200-072, Portugal \\ khantermail@gmail.com
}

\begin{abstract}
The paper presents a generalized analysis of the results of scanning electron microscopy, energy dispersive spectroscopy, and TG/DSC analysis of electrochemical exfoliation products from two types of initial graphite raw materials at different process temperatures in solutions of potassium hydroxide $(\mathrm{KOH})$ and sulfuric acid $\left(\mathrm{H}_{2} \mathrm{SO}_{4}\right)$. It is shown that an increase in the concentration of an alkaline electrolyte in the range from 0.1 to $1.0 \mathrm{~mol} \cdot \mathrm{L}^{-1}$ promotes the intensification of the process of separation and splitting of graphite into fragments. In the case of the formation of large fragments, the product contains a significant amount of intercalated potassium ions, which are not removed when the material is washed off. The products of electrochemical exfoliation of the spent electrocontact graphite material demonstrate structural heterogeneity, contain a significant amount of functional groups and impurities of the amorphous phase. Thermogravimetric curves have several sections of sample weight reduction. After heating these materials in an inert atmosphere to $900{ }^{\circ} \mathrm{C}$, the total weight loss reaches $66 \%$. From a thermally expanded graphite foil, samples of nanographites, extremely homogeneous in chemical composition, with increased thermal stability and a minimum number of surface defects were obtained. The total weight loss of the samples when heated in an inert atmosphere to $900{ }^{\circ} \mathrm{C}$ does not exceed $17 \%$. It was shown that the replacement of an alkaline electrolyte with a sulfuric acid solution leads to an increase in the number of defects in the product.
\end{abstract}

Keywords: scanning electron microscopy; thermogravimetry; differential scanning calorimetry; nanographite; electrochemical exfoliation; thermally expanded graphite.

For citation: Khan YuA, Dyachkova TP, Bakunin ES, Obraztsova EYu, Rukhov AV, Morais S. A study of the structure and morphology of the graphite electrochemical exfoliation products. Journal of Advanced Materials and Technologies. 2021;6(4):267-278. DOI: 10.17277/jamt.2021.04.pp.267-278

\section{Исследование структуры и морфологии продуктов электрохимической эксфолиации графита}

\author{
Ю. А. Хан ${ }^{\mathrm{a} \bowtie}$, Т. П. Дьячкова ${ }^{\mathrm{a}}$, Е. С. Бакунин ${ }^{\mathrm{a}}$, \\ Е. Ю. Образцова ${ }^{a}$, А. В. Рухов ${ }^{\mathrm{a}}$, С. Морайш \\ ${ }^{\mathrm{a}}$ Тамбовский государственный технический университет, \\ ул. Советская, 106, Тамбов 392000, Российская Федераичя, \\ b Высший инженерный Институт Порту, Политехнический Институт Порту, Порту, 4200-072, Португалия
}

khantermail@gmail.com

\begin{abstract}
Аннотация: В статье представлен обобщенный анализ результатов сканирующей электронной микроскопии, энергодисперсионной спектроскопии и ТГ/ДСК-анализа продуктов электрохимической эксфолиации из двух типов исходного графитового сырья при различных температурах процесса в растворах гидроксида калия (КОН) и серной кислоты $\left(\mathrm{H}_{2} \mathrm{SO}_{4}\right)$. Показано, что увеличение концентрации щелочного электролита в интервале от 0,1 до 1,0 моль/л способствует интенсификации процесса расслоения и расщепления графита на фрагменты. В случае формирования крупных фрагментов продукт содержит значительное количество интеркалированных ионов калия, не удаляющихся при отмывке материала. Продукты электрохимической эксфолиации отработанного
\end{abstract}


электроконтактного графитового материала демонстрируют структурную неоднородность, содержат значительное количество функциональных групп и примесей аморфной фазы. Термогравиметрические кривые имеют несколько участков снижения массы образцов. После нагревания этих материалов в инертной атмосфере до $900{ }^{\circ} \mathrm{C}$ суммарная убыль массы достигает 66 \%. Из фольги терморасширенного графита получены крайне однородные по химическому составу образцы нанографитов с увеличенной термической стабильностью и минимальным количеством поверхностных дефектов. Суммарная убыль массы образцов при нагревании в инертной атмосфере до $900{ }^{\circ} \mathrm{C}$ не превышает 17 \%. При этом показано, что замена щелочного электролита раствором серной кислоты приводит к увеличению числа дефектов в продукте.

Ключевые слова: сканирующая электронная микроскопия; термогравиметрия; дифференциальная сканирующая калориметрия; нанографит; электрохимическая эксфолиация; терморасширенный графит.

Для цитирования: Khan YuA, Dyachkova TP, Bakunin ES, Obraztsova EYu, Rukhov AV, Morais S. A study of the structure and morphology of the graphite electrochemical exfoliation products. Journal of Advanced Materials and Technologies. 2021;6(4):267-278. DOI: 10.17277/jamt.2021.04.pp.267-278

\section{Introduction}

Carbon is a unique chemical element that is the basis of organic substances and forms many allotropic modifications, among which nanostructures occupy a special place. The most common simple carbon-based substances are graphite and diamond. Contrary to popular belief, the chemical bonds between carbon atoms in graphite layers are stronger than in diamond. The key difference that determines the difference in the mechanical properties of these substances is due to the peculiarities of their crystalline structure. The diamond is structured by means of a three-dimensional lattice. Graphite consists of numerous two-dimensional sheets connected by van der Waals forces. Each such sheet (layer) is extremely strong; however, individual sheets can slide relative to each other.

Graphene was produced in 2004 by A. Geim and K. Novoselov from a separate stable layer of graphite [1]. Due to its layered structure graphite exhibits anisotropy of properties; however, graphene is devoid of this drawback due to its planar structure, which opens up great prospects for its application. However, it should be noted that it is rather difficult to stabilize a single graphene layer, and today technologies for producing such a material in mass quantities are almost non-existent. Numerous publications describe methods of a close analogue of graphene, nanographite [2-5]. Unlike graphite, it consists of a small number of graphene layers, which opens up the possibility for the manifestation of nanoscale effects.

One of the first to describe was the method of producing carbon nanostructures by electric arc evaporation of a graphite target in the presence of hydrogen. The process is very energy intensive. It requires the discharge current of about 100-150 A at voltages up to $60 \mathrm{~V}$. In this case, a mixture of various products is formed, among which low-layer nanographites, nanotubes, and nanotubes are found [6].

Some research groups believe that the most appropriate approach for the formation of the structure of nanographite is the "bottom-up" approach. This includes the currently most wellknown method - pyrolysis of carbon-containing gases on a catalyst at a temperature of $600-700{ }^{\circ} \mathrm{C}$ [7] with subsequent heat treatment up to $2800{ }^{\circ} \mathrm{C}$. Methods of non-catalytic synthesis are also being actively developed [8], where silicon compounds after multi-stage purification are active centers for the formation of carbon nanostructures.

A number of studies focus on the production of low-layer graphene materials by reduction of graphene oxide. For example, in [9], nanographite was obtained by the reduction of single-layer graphene oxide with hydrazine hydrate in an aqueous medium. To intensify the process, the reaction mass was acted upon by microwave radiation.

In $[10,11]$, nanographite was found in the products of heat treatment $\left(T>1650^{\circ} \mathrm{C}\right)$ of nanodiamonds preliminarily purified in acid in an inert and reducing atmosphere.

However, the most common methods for producing nanographite are various options for exfoliating graphite. Thus, in $[10,12]$, a productive method for producing nanographite by thermal cleavage of oxidized graphite at $1050{ }^{\circ} \mathrm{C}$ was proposed.

As can be seen, for the implementation of many of the proposed methods for producing nanographites, it is necessary to maintain extremely high temperatures, the use of highly toxic reagents and serious requirements are also imposed on the quality of the feedstock. All of these factors combine to limit the scaling up of such laboratory techniques.

A relatively new and promising method for producing nanographite is electrochemical exfoliation from graphite [13, 14]. Its essence lies in the 
exfoliation of nanographite flakes from a graphite electrode. To stabilize the product, it is proposed to add surfactants to the electrolyte [15], but sometimes it is possible to do without them [16]. The distinctive features of this method are relative simplicity, environmental friendliness, high productivity and the ability to vary the operating parameters of the process in a wide range in the absence of special requirements for the electrolytic media used and temperature conditions.

Obviously, by means of electrochemical exfoliation of graphite, it is possible to obtain products that are noticeably different in their structural and morphological characteristics and chemical composition and are suitable for use in various branches of technology.

Methods of spectral analysis are successfully used to diagnose carbon nanostructures [17, 18]; however, the most illustrative are the methods of electron microscopy. They provide visual information about the phase composition and surface structure of the material, as well as about its near-surface layers [19-21]. Modern electron microscopes with additional energy dispersive modules provide information on the qualitative and quantitative chemical composition of the materials under study.

Thermal analysis methods allow studying the behavior of materials under conditions of increasing temperatures. The most common method is combined thermogravimetric (TG) and differential scanning calorimetric (DSC) analysis. With an increase in temperature, a decrease in the mass of the sample is recorded, indicating the presence of various phases and impurities in the material. The DSC analysis provides additional information on exothermic and endothermic processes at certain stages of heating [22].

To obtain comprehensive information about the processes occurring during electrochemical exfoliation at various stages and under various conditions, it is important to conduct a comprehensive analysis using various complementary methods. Electron microscopy, which makes it possible to assess the morphology and structure of particles, can be supplemented with information from synchronously conducted energy dispersive analysis, which makes it possible to establish the elemental composition of the material. The TG/DSC analysis allows confirming the presence and assessing the content of the amorphous phase, impurities and functional groups.

In this regard, the purpose of this study is a generalized analysis of the data of scanning electron microscopy, thermogravimetry, and differential scanning calorimetry of nanographite samples obtained by electrochemical exfoliation of graphite raw materials under various conditions.

\section{Materials and methods}

\subsection{Materials}

To implement the process of electrochemical exfoliation, graphite electrodes were used in two variations - Graflex thermally expanded graphite (TEG) foil (Unikhimtek, Russia) and molded graphite electrical contact material (MGECM), (AVERS Graphite, Russia).

Solutions of sulfuric acid and potassium hydroxide prepared by dilution with distilled water from concentrated $\mathrm{H}_{2} \mathrm{SO}_{4}$ (analytical grade, EKOS-1, Russia) and dry potassium hydroxide $\mathrm{KOH}$ (analytical grade, EKOS-1, Russia) were used as electrolytes.

\subsection{Methods of producing material}

The studied samples of nanographite were produced by the method of electrochemical exfoliation of graphite in thermostated two-electrode cells at direct and alternating electric currents. To produce the first sampling, the process was implemented in a two-electrode pulsed cell with graphite electrodes with rectangular pulse duration of $1 \mathrm{~s}$ and a current density of $0.1 \mathrm{~A} \cdot \mathrm{cm}^{-2}$. To produce the second sampling, the process was carried out at a constant current with a density of $0.25 \mathrm{~A} \cdot \mathrm{cm}^{-2}$ in a cell with a platinum cathode and a graphite anode.

A $0.15 \mathrm{M} \mathrm{H}_{2} \mathrm{SO}_{4}$ solution and $\mathrm{KOH}$ solutions with concentrations of $0.1,0.5$, and $1.0 \mathrm{M}$ served as electrolytes in various experiments.

Exfoliation was carried out at temperatures of 30,50 and $70{ }^{\circ} \mathrm{C}$.

In the case of using expanded graphite foil as a starting material, the electrochemical exfoliation product was post-processed in an UM-2 ultrasonic bath for 8 hours.

Colloidal systems resulting from electrochemical exfoliation were centrifuged. The precipitated materials isolated as a result were repeatedly washed on a filter with distilled water until neutral $\mathrm{pH}$, and then dried in a vacuum drying cabinet for $24 \mathrm{~h}$ at $40{ }^{\circ} \mathrm{C}$.

The conditions for producing experimental samples are summarized in Table 1.

\subsection{Characterization}

A FEI Quanta 400FEG ESEM/EDAX Genesis X4 $M$ device (ThermoFisher, USA) was used to obtain synchronous data from scanning electron microscopy (SEM) and energy dispersive analysis (EDA). 
Table 1. Designations and conditions

for producing experimental samples of nanographite

\begin{tabular}{cccccc}
\hline Sample & Cell type & $\begin{array}{c}\text { Raw graphite } \\
\text { material }\end{array}$ & Electrolyte & $\begin{array}{c}\text { Electrolyte } \\
\text { concentration, mol } \cdot \mathrm{L}^{-1}\end{array}$ & Temperature, ${ }^{\circ} \mathrm{C}$ \\
\hline 1 & & & 0.1 & 30 \\
2 & & & 0.5 & \\
3 & & & 1.0 & 50 \\
4 & & $\mathrm{KOH}$ & 0.1 & \\
5 & ACcell & MGECM & & 0.5 & \\
6 & & & 1.0 & 70 \\
7 & & & 0.1 & \\
8 & & & 0.5 & \\
9 & & & 1.0 & \\
10 & & TEG foil & & 0.1 & \\
11 & DCcell & TEG foil & $\mathrm{H}_{2} \mathrm{SO}_{4}$ & 0.15 & \\
\hline
\end{tabular}

The thermal analysis was carried out on an STA 449 F3 Jupiter device (Netzsch, Germany) in a nitrogen atmosphere and a temperature range of $30-900{ }^{\circ} \mathrm{C}$ at a heating rate of $10 \mathrm{~K} \cdot \mathrm{min}^{-1}$.

\section{Results and Discussion}

Fig. 1 shows the energy dispersive spectra (EDS) of samples no. 1-3 (Table 1) produced at a temperature of $30{ }^{\circ} \mathrm{C}$. They allow one to obtain a semi-quantitative assessment of the elemental composition of materials and qualitatively assess the changes that occur when varying the modes of electrochemical exfoliation. Table 2 presents data on the relative heights of the peaks of elements $(\mathrm{C}, \mathrm{O}, \mathrm{Si}$, $\mathrm{S}, \mathrm{K})$ in the EDS.

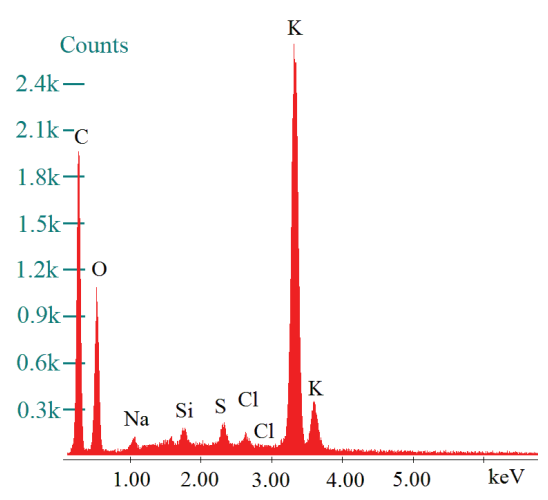

(a)

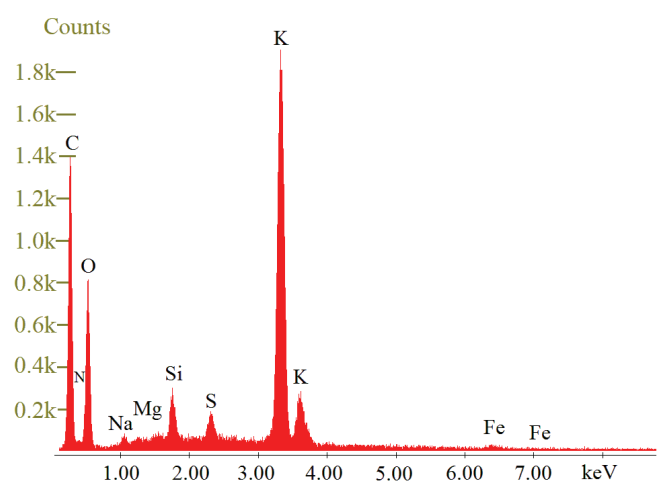

(b)
In the composition of samples no. 1-3, in addition to carbon and oxygen, potassium was identified in significant quantities, which was part of the alkaline electrolyte. This fact allows us to conclude that in the course of the electrochemical process it intercalates between the layers of graphite and remains there, as a result of which it cannot be removed when the material is washed off.

The ratio between the intensities of the spectral lines of carbon and oxygen for samples 1 and 2 was approximately the same and is $\approx 1.7-1.8$. For sample no. 3 , this ratio reached $\approx 1.1$, which indicates a higher content of oxide functional groups in its composition.

The rest of the elements $(\mathrm{Na}, \mathrm{Mg}, \mathrm{Cl}, \mathrm{Si}, \mathrm{S})$ are present in small amounts. It can be assumed that they are included in the modifiers of the MGECM, from which the samples were produced.

Fig. 1. EDS of the MGECM electrochemical exfoliation products in an alkaline electrolyte with a $\mathrm{KOH}$ concentration of $0.1(a), 0.5(b)$ and $1.0(c)$ at $30^{\circ} \mathrm{C}$ 
Table 2. Energy dispersive spectroscopy data for experimental samples

\begin{tabular}{cccccc}
\hline \multirow{2}{*}{ Sample } & \multicolumn{5}{c}{ Relative height of the main peak of the element in the EDS, cps } \\
& $\mathrm{C}$ & $\mathrm{O}$ & $\mathrm{Si}$ & $\mathrm{S}$ & $\mathrm{K}$ \\
\hline 1 & 1963 & 1090 & 176 & 212 & 2656 \\
2 & 1397 & 816 & 293 & 184 & 1906 \\
3 & 988 & 904 & 623 & 108 & 2319 \\
4 & 970 & 560 & 133 & 203 & 2007 \\
5 & 1434 & 1081 & 768 & 181 & 1985 \\
6 & 931 & 912 & 896 & 1065 & 667 \\
7 & 1468 & 1334 & 541 & 188 & 734 \\
8 & 1599 & 1041 & 673 & 364 & 2614 \\
9 & 1405 & 605 & 540 & 467 & 319 \\
10 & 5833 & 78 & - & - & 88 \\
11 & 3308 & 168 & 76 & 276 & 114 \\
\hline
\end{tabular}

Differences in the structure of the samples are also evident. On the surface of sample no. 1 (Fig. $2 a$ ), there are many small fragments of relatively regular shape. Nanographite flakes with large lateral dimensions and free surface are not found. When using an alkaline electrolyte of medium concentration (sample no. 2, Fig. 2b), the volume of the product contains large fragments of graphite with transverse dimensions of $100-150 \mu \mathrm{m}$, with a partially free surface. In addition, there is a large number of finecrystalline (in the form of a regular shape) and amorphous particles (visually irregular shape with an inhomogeneous surface), both in the form of a free phase and on the surface of larger fragments. Sample no. 3 (Fig. 2c) is noticeably aggregated. At higher resolution, it can be seen that the surface of the agglomerates is fine-grained, with practically no smooth areas.
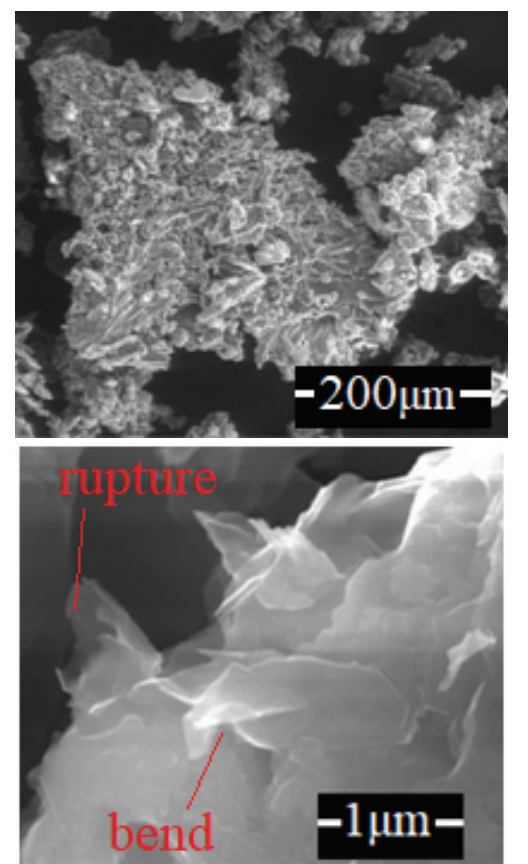

(a)
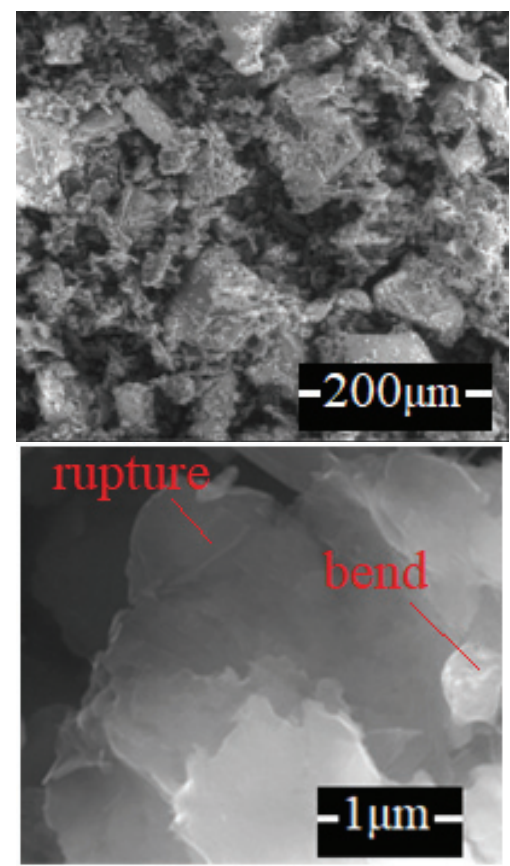

(b)
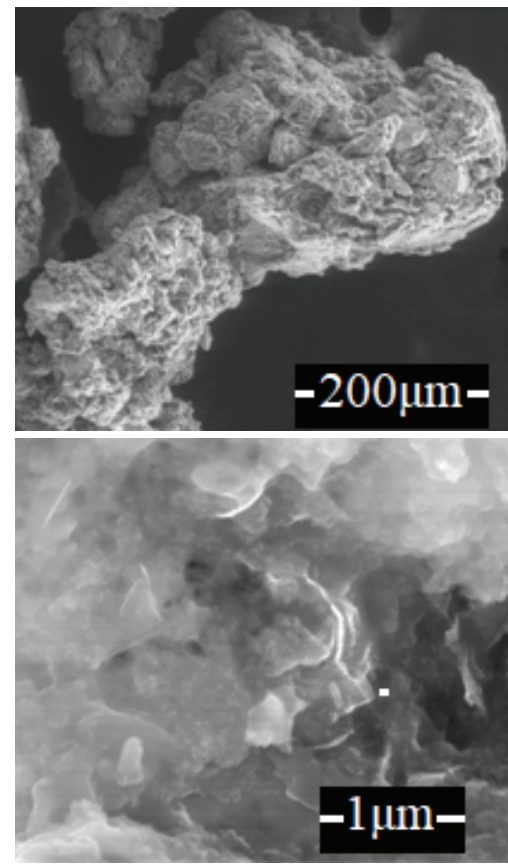

(c)

Fig. 2. SEM images at a lower (upper row) and higher (lower row) resolution of the MGECM electrochemical exfoliation products in an alkaline electrolyte with a $\mathrm{KOH}$ concentration of $0.1(a), 0.5(b)$ and $1.0(c)$ at $30{ }^{\circ} \mathrm{C}$ 
It is possible to note a regular change in the nature of the defectiveness of the material with an increase in the concentration of alkaline electrolyte on the example of samples nos. 1-3. As a result of exfoliation, both edge defects in the form of bends and breaks, and destruction in the center of the layers, in places of possibly existing surface distortions can be formed in the form of breaks, "wounds", holes and bends. Moreover, edge defects are found mainly on low-layer fragments, but they can also be in the center on multilayer ones.

The first sample was produced in a $0.1 \mathrm{M}$ solution and contained a large number of defects both on the inner surface and at the edges of the fragments (Fig. 2a). Internal surface defects were of various types and slight bends, and numerous bends and breaks were at the edges. With an increase in the electrolyte concentration (Fig. 2b), nanographite with fewer layers was formed, as a result of which edge defects began to prevail (sample no. 2). In sample no. 3 , which was produced in a $1.0 \mathrm{M}$ solution, edge defects were represented by discontinuities (Fig. 2c). Taking into account the granular nature of the surface of the material, it can be assumed that numerous exfoliated fragments in this case had small lateral dimensions, and as a result of their subsequent separation from the dispersion medium and drying, their aggregation occurred.

Samples nos. 4-6 produced at $50{ }^{\circ} \mathrm{C}$ (Fig. 3), as well as samples nos. 1-3, contained a significant amount of intercalated potassium. In the composition of sample no. 6 , the concentration of potassium was slightly lower, while the relative height of the peaks due to the presence of sulfur and silicon in the energy dispersive spectra became higher. This may be due to both more efficient delamination of the graphite material and the heterogeneity of the composition of the feedstock. The tendency to a decrease in the $\mathrm{C}: \mathrm{O}$ ratio with an increase in the electrolyte concentration is also traced here; therefore, in a $1.0 \mathrm{M}$ alkali solution, a material with the highest degree of functionalization by oxygen-containing groups is formed.

According to SEM data, sample no. 4 (Fig. $4 a$ ) consisted of fragments of an inhomogeneous size with a relatively smooth surface. Of the plane defects, slight bends or breaks of the "wounds" type were found. Edge defects were prevalent, often with gross tears.

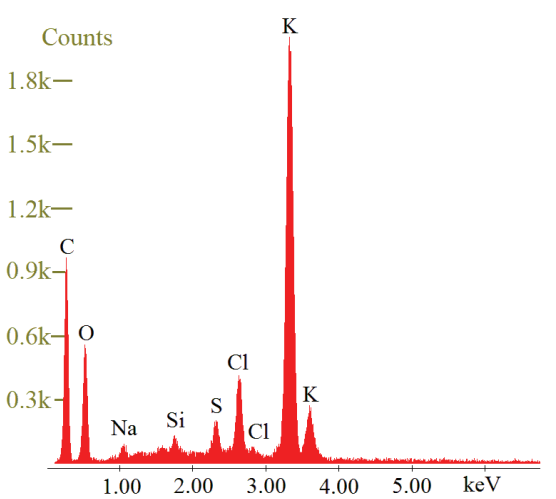

(a)

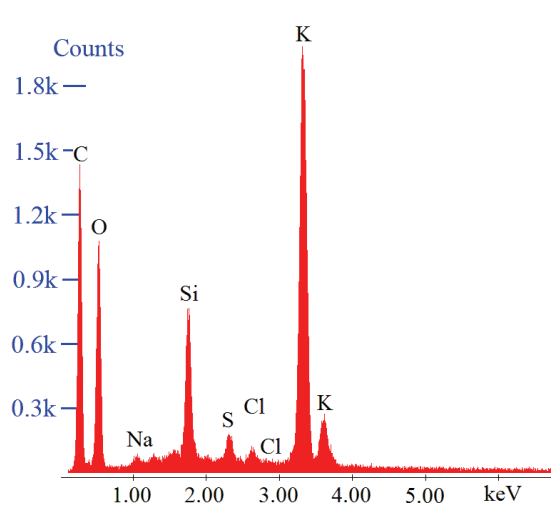

(b)

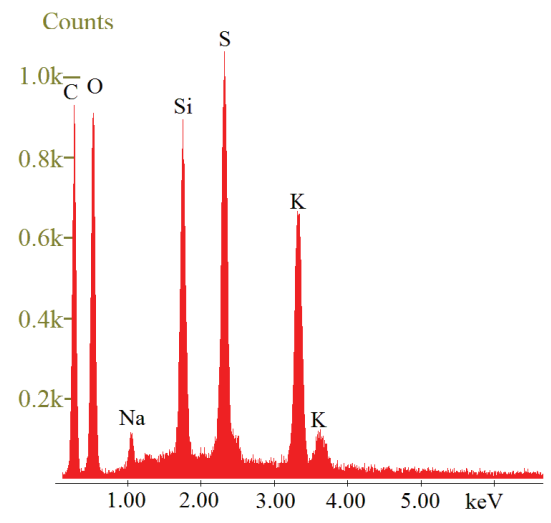

(c)

Fig. 3. EDS of the MGECM electrochemical exfoliation products in an alkaline electrolyte with a $\mathrm{KOH}$ concentration of $0.1(a), 0.5(b)$ and $1.0(c)$ at $50{ }^{\circ} \mathrm{C}$

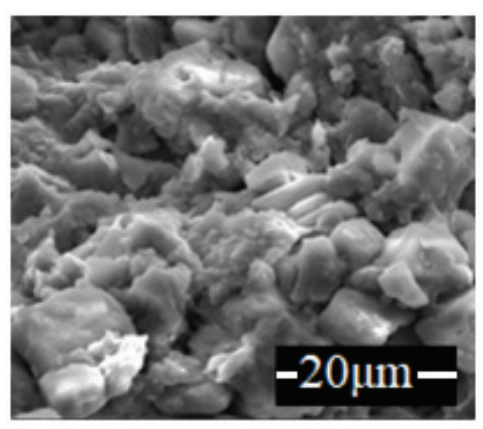

(a)

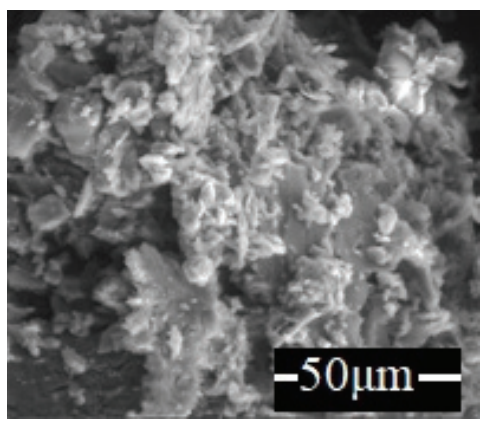

(b)

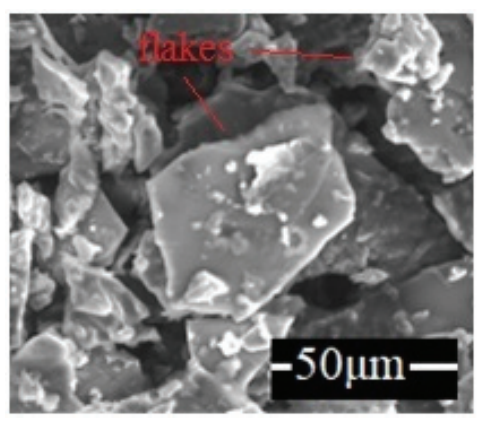

(c)

Fig. 4. SEM images of the MGECM electrochemical exfoliation products in an alkaline electrolyte with a $\mathrm{KOH}$ concentration of $0.1(a), 0.5(b)$, and $1.0(c)$ at $50{ }^{\circ} \mathrm{C}$ 
Sample no. 5 (Fig. 4b) contained particles with a rough surface. The sizes of individual granules were approximately the same as in the composition of sample no. 2, produced in an electrolyte with the same concentration, but at a lower temperature. Surface defects such as scratches and fractures are present. Also, edge defects in the form of bends were clearly identified.

Sample no. 6 (Fig. 4c) consisted of a large number of flat flakes with an average planar size of more than $50 \mu \mathrm{m}$ and a relatively smooth surface. Hole defects were present on the inner layers, rather than on the surface ones. The edges of the scales were characterized by a different shape, without bends.

The comparison of the images shown in Figs. $4 a-c$ brings us to the conclusion that at a low concentration of alkali in the electrolyte, exfoliation is not efficient enough. In an electrolyte with a $\mathrm{KOH}$ concentration of $0.5 \mathrm{M}$, small fragments of visually irregular shape are cleaved from the surface. The formation of nanographite plates, which are identified in SEM images as individual flakes, begins to be observed only when a $1.0 \mathrm{M} \mathrm{KOH}$ solution is used.

As the temperature rose to $70{ }^{\circ} \mathrm{C}$, materials with a lower relative content of potassium were formed (Fig. 5), which may indicate both a more efficient separation of layers and the possibility of efficient removal of intercalated ions during washing of the material, and a less intensive introduction of electrolyte ions into the interlayer space of graphite.

As the analysis of SEM images of the produced samples shows (Fig. 6), both take place in different cases. Sample no. 7 (Fig. 6a) consists of individual elongated rounded globules, the average length and diameter of which are approximately 1.0 and $0.5 \mu \mathrm{m}$, respectively. Small ulcerations are present on the surface of these particles, but there are no obvious signs of stratification of the material.

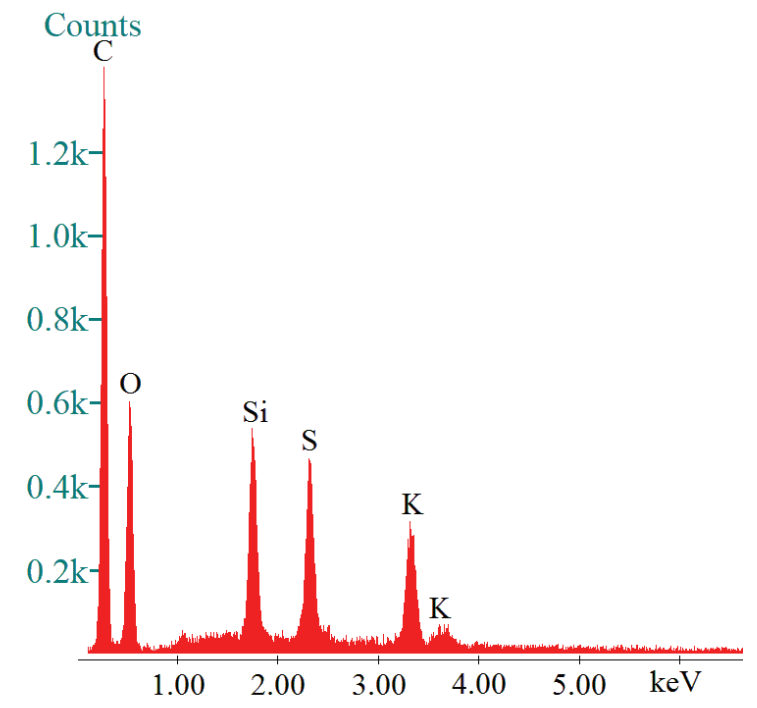

Fig. 5. Typical EDS of the MGECM electrochemical exfoliation products in an alkaline electrolyte at $70{ }^{\circ} \mathrm{C}$ (sample no. 9)

The image of sample no. 8 (Fig. $6 b$ ) shows signs of stratification of individual fragments of the starting material, which indicates a more active course of the exfoliation process with an increase in the concentration of alkaline electrolyte.

Sample no. 9 (Fig. 6c) contains many small nanographite flakes separated from the initial material.

When using expanded graphite foil as the initial electrode material under the same conditions $(1.0 \mathrm{M}$ $\mathrm{KOH}, 70{ }^{\circ} \mathrm{C}$ ), a material with a minimum potassium content and nanographite containing low-defect flakes characterized by large planar dimensions is formed (sample no. 10, Fig. 7). In this case, the internal defects of the graphene layers were poorly expressed cracks. The forming scales had rough edges.

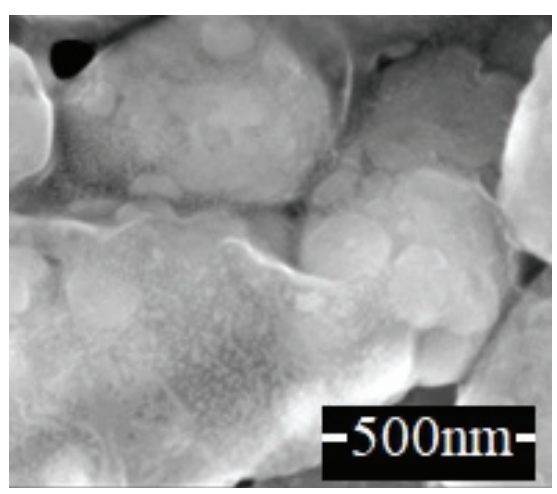

(a)

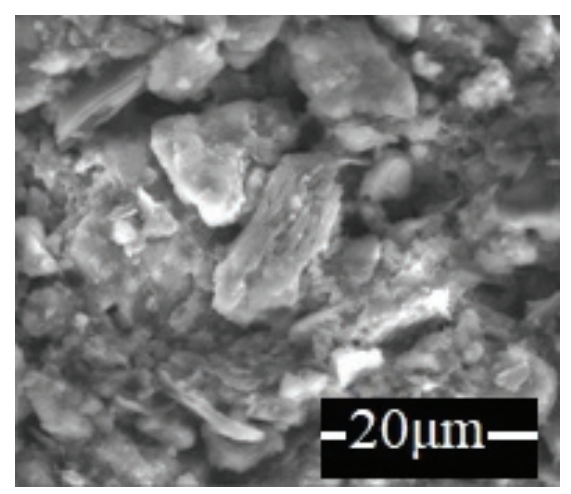

(b)

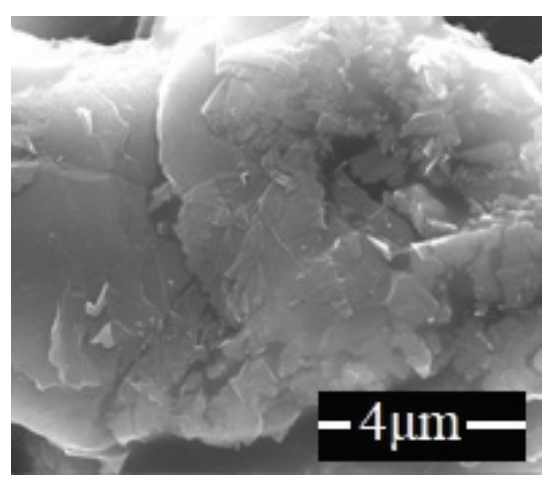

(c)

Fig. 6. SEM images of the MGECM electrochemical exfoliation products in an alkaline electrolyte with a $\mathrm{KOH}$ concentration of $0.1(a), 0.5(b)$, and $1.0(c)$ at $70{ }^{\circ} \mathrm{C}$ 

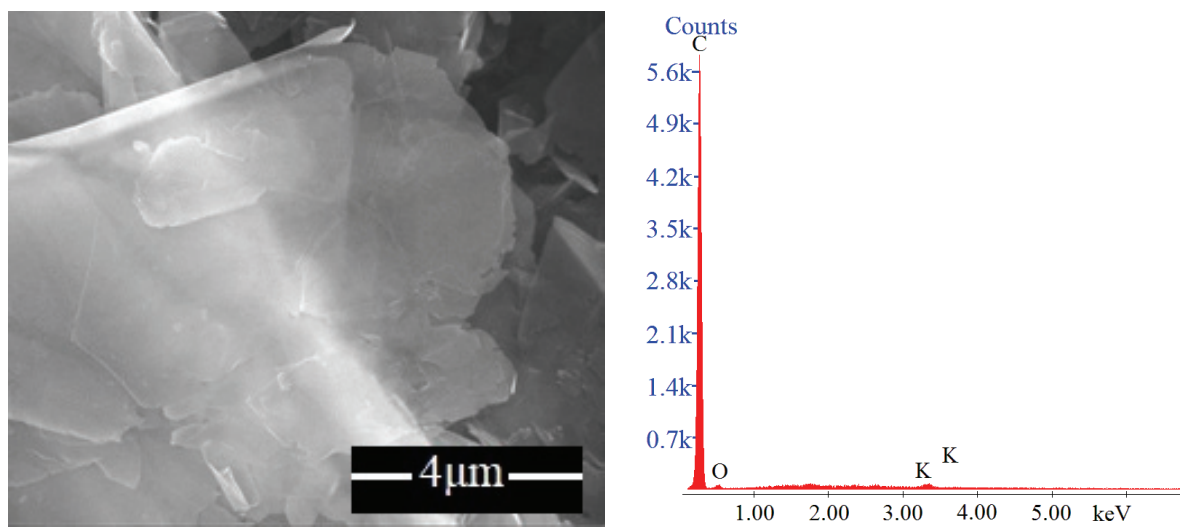

Fig. 7. SEM-EDS data of nanographite obtained by using TEG foil as an electrode

When an $\mathrm{H}_{2} \mathrm{SO}_{4}$ solution was used as an electrolyte, a material with a dense and fairly uniform packing of layers was formed from the expanded graphite foil (sample no. 11, Fig. 8). Surface fragments differed in size and form edge defects such as bends, creases, and possibly cuts. There were also a few defects on the surface of the formed particles, however, the surface of the material remained smooth.

Additional information on the composition and structure of the obtained samples was obtained based on the data of synchronous thermal analysis. On the TG / DSC curves of the samples produce at $30{ }^{\circ} \mathrm{C}$ (Fig. 9) in alkaline electrolytes, several characteristic intervals are distinguished. A decrease in the mass of samples with an increase in temperature to $150{ }^{\circ} \mathrm{C}$ occurred as a result of the removal of adsorbed moisture. Its content is 5 and $8 \%$ for samples nos. 1 and 2, respectively. The next section of the change in the mass of sample no. 1 (Fig. 9a) corresponds to the temperature range $160-190{ }^{\circ} \mathrm{C}$, in which, according to [23], the decomposition of labile oxygencontaining groups occurs. At $300-350{ }^{\circ} \mathrm{C}$, the decomposition of the amorphous phase and functional groups occurs [24]. A sharp decrease in the mass of the sample at temperatures above $800{ }^{\circ} \mathrm{C}$

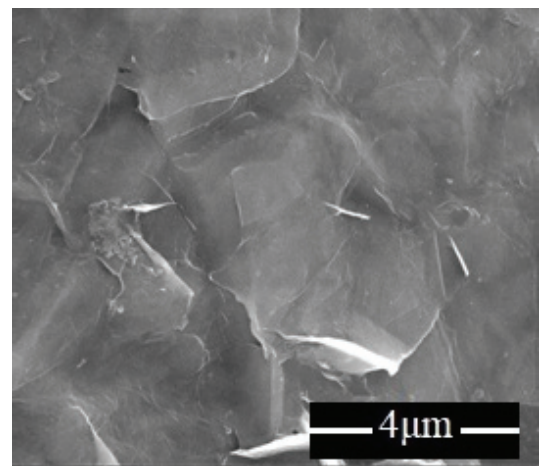

Fig. 8. SEM image of a material sample obtained by TEG foil electrochemical exfoliation in sulfuric acid electrolyte was due to the removal of thermal destruction products of a more thermally stable material, which, presumably, were exfoliated particles of nanographite. According to [25], they are supposed to decompose at a higher temperature than the amorphous phase, but at a lower temperature than graphite. The residual mass of the samples in this case did not exceed $34 \%$.

On the TG/DSC curves of sample no. 2 (Fig. 9b), the sections were not so isolated, which indicates a greater homogeneity of the material, which generally corresponds to the data of electron microscopy. In addition, it is characterized by slightly higher stability at temperatures above $800{ }^{\circ} \mathrm{C}$. The residual mass of the sample was $52 \%$.

For the samples produced at a higher temperature, the same tendency towards a change in the character of the TG curves with an increase in the concentration of the alkaline electrolyte was observed (Fig. 10). Thermal decomposition of sample no. 4, obtained using $0.1 \mathrm{M}$ alkali, included the largest number of stages, which indicates the content of both a large number of functional groups and the presence of heterogeneous (including amorphous) carbon fractions. In the investigated temperature range, this sample lost $66 \%$ of its mass.

The material produced in $0.5 \mathrm{M} \mathrm{KOH}$ (sample no. 5) was more thermally stable over the entire investigated temperature range. However, the most homogeneous material was sample no. 6 , obtained in a $1.0 \mathrm{M}$ alkali solution, which also fully agrees with the data of electron microscopy. The residual mass of samples no. 5 and 6 was 59 and $54 \%$ of the initial mass, respectively.

The TG curves of the products of electrochemical exfoliation of graphite in alkaline media at $70{ }^{\circ} \mathrm{C}$ (Fig. 11) were relatively uniformly decreasing lines. This may indicate a high intensity of the electrochemical process, which contributes to the production of materials that are more homogeneous in their composition. The residual mass of samples nos. 7-9 varied in the range of $48-55 \%$. 


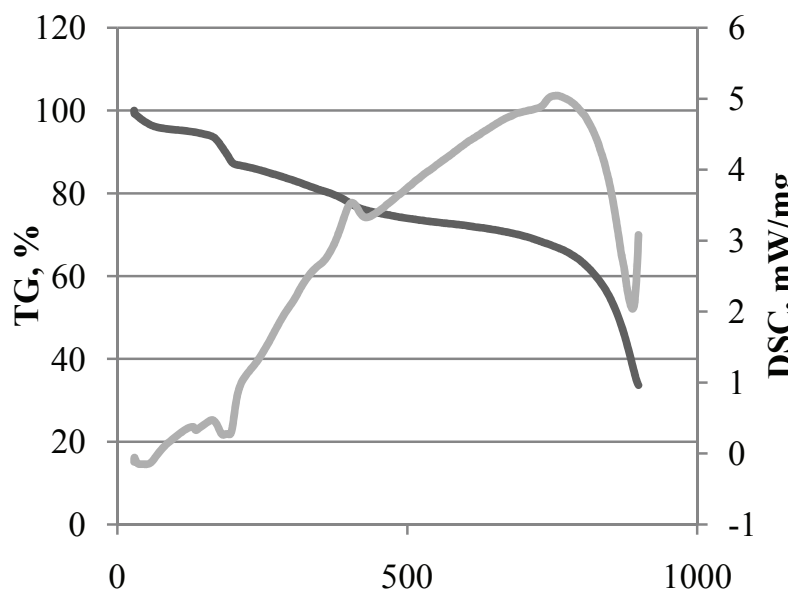

Temperature, ${ }^{\circ} \mathrm{C}$

(a)

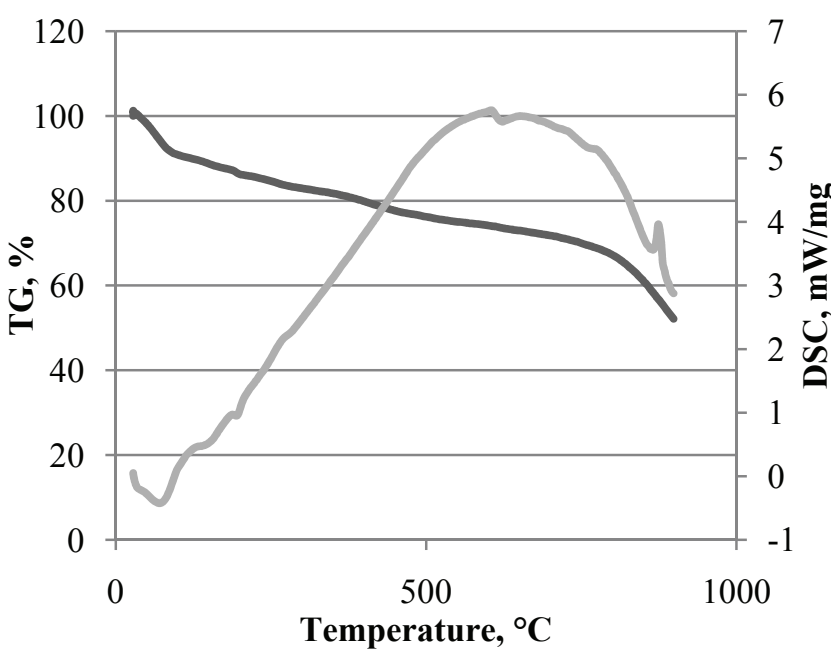

(b)

Fig. 9. TG/DSC data of nanographite obtained at $30{ }^{\circ} \mathrm{C}$ using an electrolyte with a concentration of $0.1(a)$ and $0.5 \mathrm{M}(b) \mathrm{M} \mathrm{KOH}$ solutions

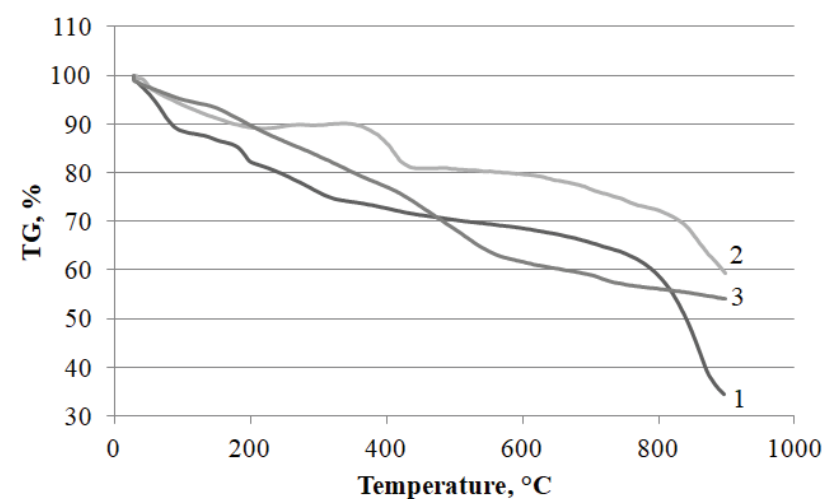

Fig. 10. TG curves of the MGECM electrochemical exfoliation products at $50^{\circ} \mathrm{C}$ in 0.1 (1), 0.5 (2) and 1.0 (3) $\mathrm{M} \mathrm{KOH}$ solutions

As mentioned earlier, based on the analysis of electron microscopy data, the most structurally pure samples of materials were produced when using expanded graphite foil as the initial graphite material. According to thermogravimetric data, samples nos. 10 and 11 were characterized by a much higher thermal stability (Fig. 12) than the products of electrochemical exfoliation of the MGECM. In the temperature range up to $900{ }^{\circ} \mathrm{C}$, the total weight loss of the samples obtained in alkaline and acidic electrolytes was 7 and $17 \%$, respectively. At the same time, the use of sulfuric acid as an electrolyte contributed to the formation of a slightly more defective product, as evidenced by the presence of an additional section on the TG curve in the temperature range of $723-783{ }^{\circ} \mathrm{C}$.

The presented data reflect the dependence of the characteristics of the products of electrochemical exfoliation of graphite on the operating parameters,

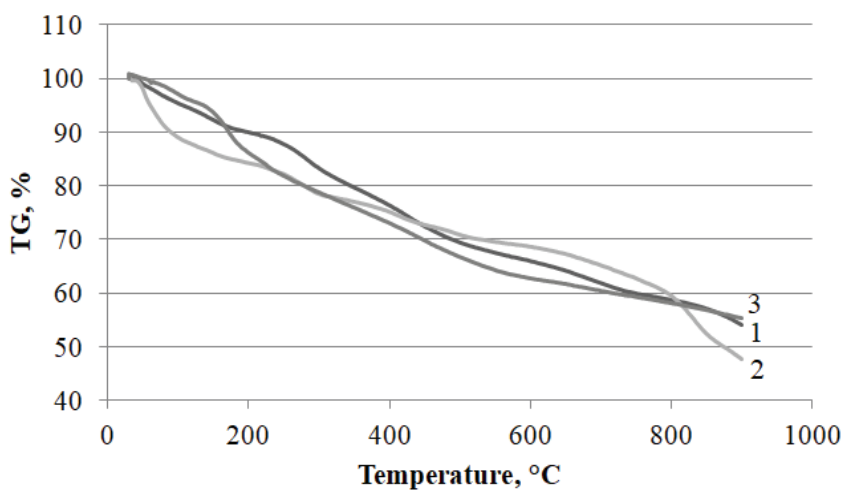

Fig. 11. TG curves of the MGECM electrochemical exfoliation products at $70^{\circ} \mathrm{C}$ in 0.1 (1), 0.5 (2) and 1.0 (3) $\mathrm{M} \mathrm{KOH}$ solutions

properties of the starting material of the electrodes, and the type and concentration of the electrolyte. This opens up possibilities for monitoring the functionalization of nanographite and the

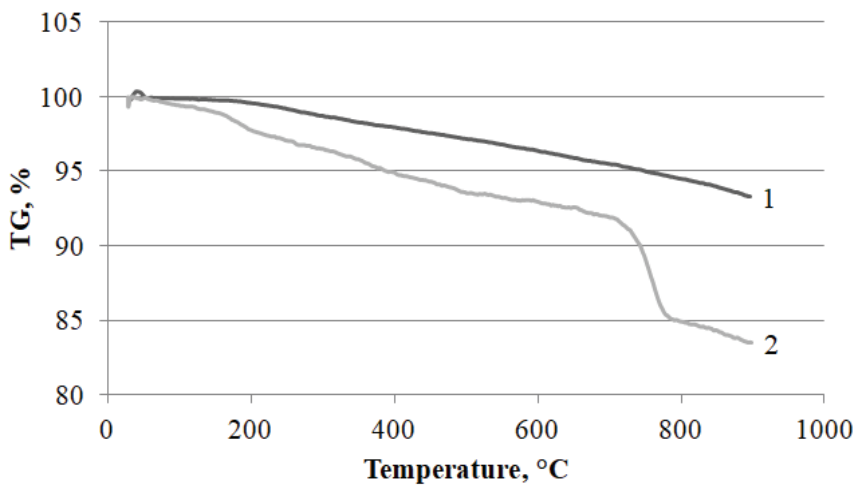

Fig. 12. TG-curves of the TEG foil electrochemical exfoliation products in solutions of $\mathrm{KOH}(1)$ and $\mathrm{H}_{2} \mathrm{SO}_{4}(2)$ 
defectiveness of its layers. Ultimately, with different versions of the electrochemical process, materials with desired properties can be obtained for use as the main components or modifying additives of nanocomposites. Nanographites with a high degree of defectiveness, even containing potassium impurities, can be used as an additive to liquid lubricants. The presence of oxygen-containing functional groups contributes to the adaptation of carbon nanostructures to polar, for example, epoxy, polymer matrices and an increase in the mechanical properties of the produced composites and their resistance to thermal and moisture aging. Defect-free nanographites are suitable for use in electrically conductive composites and composites based on non-polar matrices. They can also be recommended as the main components of electrodes for sensor systems.

\section{Conclusions}

As part of this study, we analyzed the data of scanning electron microscopy, energy dispersive spectroscopy, and thermogravimetry of the products of electrochemical exfoliation of graphite obtained by varying the temperature conditions, the type and concentration of the electrolyte and the electrode material. Samples obtained from spent graphite (MGECM) contain a large amount of impurities in the form of intercalated potassium ions, functional groups, and an amorphous phase. Products characterized by a more ordered structure and homogeneity were obtained using Graflex thermally expanded graphite foil as a starting material. It was found that an increase in the concentration of an alkaline electrolyte promotes the intensification of the process of graphite exfoliation during the electrochemical process. Replacing the alkaline electrolyte with sulfuric acid contributes to the formation of a product with a large number of defects.

\section{Funding}

This study was supported by the grant from the Russian Foundation for Basic Research (Project no. 18-29-19 150 MK).

\section{Acknowledgements}

The authors are thankful to Rui Rocha and CEMUP "Centrode Materiais da Universidade do Porto" for the SEM work.

\section{Conflict of interests}

The authors declare no conflict of interest.

\section{References}

1. Mbayachi VB, Ndayiragije E, Sammani T, Taj S, Mbuta ER, Khan AU. Graphene synthesis, characterization and its applications: A review. Results in Chemistry. 2021;3:100163. DOI:10.1016/ j.rechem.2021.100163

2. Cui X, Sun S, Han B, Yu X, Ouyang J, Zeng S et al. Mechanical, thermal and electromagnetic properties of nanographite platelets modified cementitious composites. Composites: Part A. 2017;93: 49-58. DOI:10.1016/j.compositesa.2016.11.017

3. Ansari S, Giannelis EP. Functionalized graphene sheet-poly (vinylidene fluoride) conductive nanocomposites. Journal of Polymer Science, Part B: Polymer Physics. 2009;47(9):888-897. DOI:10.1002/ polb. 21695

4. Stankovich S, Dikin DA, Dommett GHB, Kohlhaas KM, Zimney EJ, Stach EA et al. Graphenebased composite materials. Nature. 2006;442:282-286. DOI:10.1038/nature04969

5. Sedaghat A, Ram MK, Zayed A, Kamal R, Shanahan N. Investigation of physical properties of graphene-cement composite for structural applications. Open Journal of Composite Materials. 2014;04(01): 12-21. DOI:10.4236/ojcm.2014.41002

6. Rao CNR, Subrahmanyam KS, Ramakrishna Matte HSS, Abdulhakeem B, Govindaraj A, Das B et al. A study of the synthetic methods and properties of graphenes. Science and Technology of Advanced Materials. 2010;11:1-15. DOI:10.1088/1468-6996/11/ $5 / 054502$

7. Cuesta N, Cameán I, Ramos A, Llobet $\mathrm{S}$, García AB. Graphitic nanomaterials from biogasderived carbon nanofibers. Fuel Processing Technology. 2016;152:1-6. DOI:10.1016/j.fuproc.2016.05.043

8. Du L, Yang L, Hu Z, Zhang J, Huang C, Sun L et al. Thickness-controlled direct growth of nanographene and nanographite film on non-catalytic substrates. Nanotechnology. 2018;29(21):1-11. DOI:10.1088/1361-6528/aab4c1

9. Stankovich S, Dikin DA, Piner RD, Kohlhaas KA, Kleinhammes A, Jia Y et al. Synthesis of graphenebased nanosheets via chemical reduction of exfoliated graphite oxide. Carbon. 2007;45(7):1558-1565. DOI:10.1016/j.carbon.2007.02.034

10. Subrahmanyam KS, Vivekchand SRC, Govindaraja A, Rao CNR. A study of graphenes prepared by different methods: characterization, properties and solubilization. Journal of Materials Chemistry. 2008;18:1517-1523. DOI:10.1039/B716536F

11. Andersson OE, Prasad BLV, Sato H, Enoki T, Hishiyama Y, Kaburagi Y et al. Structure and electronic properties of graphite nanoparticles. Physical Review B. 1998;58(24):16387-16395. DOI:10.1103/PhysRevB.58. 16387 
12.Schniepp HC, Li JL, McAllister MJ, Sai H, Herrera-Alonso M, Adamson DH et al. Functionalized Single Graphene Sheets Derived from Splitting Graphite Oxide. The Journal of Physical Chemistry $B$. 2006;110(17):8535-8539. DOI:10.1021/jp060936f

13. Obraztsova EYu, Degtyaryov AA, Rukhov AV, Bakunin ES. Physicochemical features of colloidal stability in polar solvents of electrochemically synthesized nanographite oxide. Vestnik Tambovskogo gosudarstvennogo tekhnicheskogo universiteta = Transactions of the Tambov State Technical University. 2019;25(1):116-122. DOI:10.17277/vestnik.2019.01 (In Russ.).

14. Obraztsova EYu, Barshutina MN, Bakunin ES, Rukhov AV, Shipovskaya AA, Shuklinov AV. Adsorption characteristics of nanographite oxide obtained from thermally expanded graphite. Mendeleev Communications. 2020;30(2):174-176. DOI:10.1016/ j.mencom.2020.03.014

15. Ma H, Shen Z. Exfoliation of graphene nanosheets in aqueous media. Ceramics International. 2020;46(14):21873-21887. DOI:10.1016/j.ceramint. 2020.05.314

16. Parvez K, Li R, Puniredd SR, Hernandez Y, Hinkel F, Wang $\mathrm{S}$ et al. Electrochemically exfoliated graphene as solution-processable, highly conductive electrodes for organic electronics. ACS Nano. 2013;7(4):3598-3606. DOI:10.1021/nn400576v

17. Koskin AP, Larichev YV, Mishakov IV, Mel'gunov MS, Vedyagin AA. Synthesis and characterization of carbon nanomaterials functionalized by direct treatment with sulfonating agents. Microporous and Mesoporous Materials. 2020;299: 1-11. DOI:10.1016/j.micromeso.2020.110130

18. Anwar A, Mohammed BS, Wahab MA, Liew MS. Enhanced properties of cementitious composite tailored with graphene oxide nanomaterial - A review.
Developments in the Built Environment. 2020;1:1-21. DOI:10.1016/j.dibe.2019.100002

19. Yang Y, Sun J, Wen J, Mo S, Wang J, Zhang Z et al. Single-atom doping in carbon black nanomaterials for photothermal antibacterial applications. Cell Reports Physical Science. 2021;2:1-14. DOI:10.1016/j.xcrp. 2021.100535

20. Moore K, Wei W. Applications of carbon nanomaterials in perovskite solar cells for solar energy conversion. Nano Materials Science. 2021;3:276-290. DOI:10.1016/j.nanoms.2021.03.005

21. Antonio M, Benega G, Silva WM, Schnitzler MC, Andrade RJE, Ribeiro H. Improvements in thermal and mechanical properties of composites based on epoxy-carbon nanomaterials - A brief landscape. Polymer Testing. 2021;98:1-13. DOI:10.1016/ j.polymertesting.2021.107180

22. Song J, Dai Z, Nan F, Li J, Zhao H, Wang L. Dopamine-modified nanographite as reinforcing filler for epoxy nanocomposite. Journal of Composite Materials. 2018;53(12):1-9. DOI:10.1177/ 0021998318807958

23. Radon A, Lukowiec D. Structure of nanographite synthesized by electrochemical oxidation and exfoliation of polycrystalline graphite. Micro \& Nano Letters. 2017;12(12):955-959. DOI:10.1049/ mnl.2017.0339

24. Favvas EP. High purity multi-walled carbon nanotubes: Preparation, characterization and performance as filler materials in copolyimide hollow fiber membranes. Separation and Purification Technology. 2014;122:262-269. DOI:10.1016/j.seppur. 2013.11.015

25. Bhattacharyya A, Joshi M. Synthesis of hybrid nanographite particles using fluidized bed system. Journal of Solid State Electrochemistry. 2011;15:19431952. DOI:10.1007/s10008-010-1215-5

\section{Информация об авторах / Information about the authors}

Хан Юлиан Александрович, аспирант, ФГБОУ ВО «Тамбовский государственный технический университет» (ФГБОУ ВО «ТГТУ»), Тамбов, Российская Федерация; ORCID 0000-0002-1813-5689; e-mail: khantermail@gmail.com

Дьячкова Татьяна Петровна, доктор химических наук, профессор, ФГБОУ ВО «ТГТУ», Тамбов, Российская Федерация; ORCID 0000-0002-48845171; e-mail: dyachkova_tp@mail.ru

Бакунин Евгений Сергеевич, кандидат технических наук, доцент, ФГБОУ ВО «ТГТУ», Тамбов, Российская Федерация; ORCID 0000-0003-48252525; e-mail: Jack1400@yandex.ru
Yulian A. Khan, Postgraduate, Tambov State Technical University (TSTU), Tambov, Russian Federation; ORCID 0000-0002-1813-5689; e-mail: khantermail@ gmail.com

Tatyana P. Dyachkova, D. Sc. (Chemistry), Professor, TSTU, Tambov, Russian Federation; ORCID 00000002-4884-5171; e-mail: dyachkova_tp@mail.ru

Evgeny S. Bakunin, Cand. Sc. (Engineering) Associate Professor, TSTU, Tambov, Russian Federation; ORCID 0000-0003-4825-2525; e-mail: Jack1400@yandex.ru 
Образцова Елена Юрьевна, кандидат технических наук, доцент, ФГБОУ ВО «ТГТУ», Тамбов, Российская Федерация; ORCID 0000-0002-76280198; e-mail: nikif83@mail.ru

Рухов Артем Викторович, доктор технических наук, профессор, заведующий кафедрой «Химия и химические технологии», ФГБОУ ВО «ТГТУ», Тамбов, Российская Федерация; ORCID 0000-00019194-8099; e-mail: artem1@inbox.ru

Морайш Симона Баррейра, кандидат химических наук, доцент, старший научный сотрудник, Политехнический Институт Порту, Порту, Португалия; ORCID 0000-0001-6433-5801; e-mail: sbm@isep.ipp.pt
Elena Yu. Obraztsova, Cand. Sc. (Engineering) Associate Professor, TSTU, Tambov, Russian Federation; ORCID 0000-0002-7628-0198; e-mail: nikif83@mail.ru

Artyom V. Rukhov, D. Sc. (Engineering), Professor, TSTU, Head of the Department "Chemistry and Chemical Technologies", Tambov, Russian Federation; ORCID 0000-0001-9194-8099; e-mail: artem1@inbox.ru

Simone Barreira Morais, $\mathrm{PhD}$ in Chemical Engineering, Associate Professor, Senior Researcher, Polytechnic Institute of Porto, Porto, Portugal; ORCID 0000-0001-6433-5801; e-mail: sbm@isep.ipp.pt

Received 13 September 2021; Accepted 18 November 2021; Published 28 December 2021

Copyright: (C) Khan YuA, Dyachkova TP, Bakunin ES, Obraztsova EYu, Rukhov AV, Morais S, 2021. This article is an open access article distributed under the terms and conditions of the Creative Commons Attribution (CC BY) license (https://creativecommons.org/licenses/by/4.0/). 